16. Roche, A. F., and Johnson, J. M.: Comparison between methods of calculating skeletal age (Greulich-Pyle). Amer. J. Phys. Anthropol, 30: 221 (1969).

17. Schoen, E. J., Solomon, I. L., and Milkovich, L.: Bone age in short boys and tall girls. Amer. J. Dis. Child., 119: 252 (1970).

18. Tanner, J. M., Whitehouse, R. H., and Healy, M. J. R.: Standards for skeletal maturity based on a study of three thousand British children. II. The scoring system of all twenty-eight bones of the hand and wrist. (Institute of Child Health, University of London M.S., 1961).

19. Vaughan, V. C.: Growth and development. In: W. E. Nelson, V. C. Vaughan, and R. J. McKay: Textbook of Pediatrics, Ed. 9, pp. 44-5I (W. B. Saunders Co., Philadelphia, 1969).

20. Waddell, J. A., Emerson, P. A., and Gunstone, R. D.: Hypoxia in bronchial asthma. Brit. Med. J., 2: 402 (1967)

21. Wilson, A. F., Suprenant, E. L., Beal, G. N.. Siegel, S. C., Simmons, D. H., and
Bennett, L. R.: The significance of regional pulmonary function changes in bronchial asthma. Amer. J. Med., 48: 416 (1970).

22. Parental consent was obtained for the $X$-rays which were included in the routine diagnostic examination of all patients.

23. The author acknowledges her gratitude to Dr. Marion M. Maresh of the Denver Child Research Council for instruction in the assessment of skeletal age and for help and advice throughout the course of this investigation.

24. This study was supported in part by Grant GRS RR 05474 from the National Institutes of Health.

25. Requests for reprints should be addressed to: H. G. Morris, M. D., National Jewish Hospital and Research Center, 3800 E. Colfax Ave, Denver, Colo. 80206 (USA).

26. Accepted for publication March 25, 1975

\title{
Comparison of Electrophoretic Mobility and Membrane Sialic Acid Content of Erythrocytes from Adult and Umbilical Cord Blood
}

\author{
STEPHEN J. LUNER AND DOROTHY SZKLAREK \\ The Gwynn Hazen Cherry Memorial Laboratories, Department of Pediatrics, Hematology-Oncology Division, \\ UCLA School of Medicine, Los Angeles, California, USA
}

\section{Extract}

Determinations of cell electrophoretic mobility at low ionic strength and of ghost sialic acid content show that erythrocytes from umbilical cord blood and from adult donors are identical in these two glycoprotein-related properties. Using streak deflection electro-

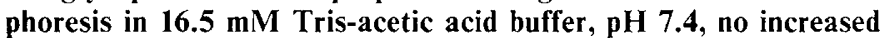
streak width indicating electrophoretic heterogeneity could be detected when mixed suspensions of adult and umbilical cord blood erythrocytes were compared with suspensions of adult cells alone. Sialic acid content of $100 \mathrm{nmol} / \mathrm{mg}$ protein were obtained for both populations of cells.

\section{Speculation}

Unlike cells involved in rapid proliferation, which carry higher negative surface charge densities than those which are nonproliferating, the umbilical cord erythrocyte exhibits the surface charge characteristics of a fully mature cell.

The bulk of the negative charge at the erythrocyte surface responsible for the electrophoretic mobility of the cell was shown by Cook et al. (1) and by Eylar et al. (4) to be due to sialic acid. Cells of the rare $M N$ variants $M^{\mathrm{g}}, \mathbf{M}^{\mathrm{k}}(9,12)$, Miltenberger classes $I I I$ and $V(9)$, as well as cells lacking the public En antigen $(5,9)$ and Tn polyagglutinable cells $(11,16)$, exhibit, in addition to their serologic abnormalities, aberrant values for membrane sialic acid content and electrophoretic mobility. In these abnormal cells, as well as in the case of neuraminidase-treated cells $(4,10)$, the percentage of decrease in sialic acid content corrsponds to the decrease in negative electrophoretic mobility. Treatment with proteolytic enzymes also decreases sialic acid, but it also unmasks new negatively charged components other than sialic acid $(10,14)$.

An increase in electrophoretic mobility for erythrocytes from umbilical cord blood over the adult value has been reported by Rottino and Angers (13) as well as by Hollan et al. (17). However, Uhlenbruck and Heggen (17) have found cord blood erythrocyte surface glycoproteins indentical with those of adults in the amount of sialic acid contained in glycopeptides removed from the cell membrane by Pronase and in the serologic reactivity of their receptors containing sialic acid.

The present study of cord blood erythrocyte electrophoretic mobility and sialic acid content was undertaken to investigate the maturation from fetal to adult surface properties. It was found, however, upon studying a large number of samples of both types of cells, that there were no differences between the two populations in both of these glycoprotein-related properties.

\section{METHODS}

Erythrocytes from blood collected in EDTA tubes were stored in modified Alsevers solution and used within a week of drawing the blood. After four washings with phosphate-buffered saline, $0.5 \mathrm{cc}$ packed cells was used to prepare ghosts for sialic acid determination, while a second aliquot was taken for electrophoretic mobility measurements.

Two washings with $40 \mathrm{ml} 5 \mathrm{mM}$ Tris buffer, $\mathrm{pH} 8$, were sufficient to prepare ghosts free of visible hemoglobin from the $0.5 \mathrm{cc}$ 
packed cells (2). The ghost suspension was adjusted to a volume of $1 \mathrm{cc}$ from which $200-\mu 1$ aliquots were taken for sialic acid determination by a modification of the thiobarbituric acid method of Warren (19). Optimum yields of free sialic acid were obtained after $30 \mathrm{~min}$ of hydrolysis of the ghost suspension in $0.1 \mathrm{~N}$ $\mathrm{H}_{2} \mathrm{SO}_{4}$. Aliquots of $20 \mu \mathrm{l}$ were taken for protein determination by the method of Lowry et al. (8)

For electrophoresis, the cells were suspended in a $16.5 \mathrm{mM}$ Tris-acetic acid buffer at $\mathrm{pH} 7.4$ which contained 5\% sucrose to prevent hemolysis. Electrophoretic mobilities were determined by the streak deflection method in an endless belt electrophoresis apparatus (15). A streak of cells, visible in darkfield illumination, is generated by injection of celis into a flowing belt of buffer pumped electromagnetically around a central iron core containing a window for viewing the cells. An electric field of $80 \mathrm{~V} / \mathrm{cm}$ at right angles to the direction of flow deflects the cells by amounts proportional to their electrophoretic mobilities. Electrophoretic mobility was calculated for erythrocytes as in Reference 15 on the basis of the separation in millimeters from a streak of a dye of known mobility (Evans blue) and from measurements of voltage and time spent in the electric field.

Mobility differences between two different types of cells are most sensitively detected by preparing a mixed suspension of the two cell types and looking for any divergence of streaks or broadening of a streak in the electric field. A $4 \%$ cell suspension in electrophoresis buffer was made for each sample of adult or umbilical cord blood. Each of these was mixed with an equal volume of a $4 \%$ suspension of cells from a single donor used as a reference. Photographs were taken of the streaks generated in the course of electrophoresis of these mixed cell suspensions, and the streak widths were measured.

\section{RESULTS}

Results of determinations of electrophoretic mobility and ghost' sialic acid content are shown in Table 1.

Of 140 adult erythrocyte specimens injected into the electrophoresis buffer belt together with reference cells from a single donor, only 2 showed any increase over the streak width obtained with reference cells alone. These two specimens showed $2-5 \%$ increases in electrophoretic mobility and in membrane sialic acid to protein ratio. A similar abnormality was found in a family member of one of the two donors.

No significant increases in streak width were detected for mixed suspensions of reference cells with each of 77 cord blood specimens. Examples of the streak patterns obtained are shown in Figure 1, a composite illustration showing streaks of $(a)$ reference cells alone, $(b)$ reference cells mixed with cord blood cells, and $(c)$ reference cells mixed with $\mathrm{M}^{\mathrm{g}}$ cells exhibiting an electrophoretic mobility $4 \%$ below normal.

To establish that storage in EDTA for 4 days has no effect on electrophoretic mobility, cells that had been so stored were mixed with cells from fresh defibrinated blood from the same donor and were found to give no increased streak width.

\section{DISCUSSION}

Uhlenbruck and Heggen (17) found that the same amount of sialic acid is removed by Pronase from equal volumes of packed erythrocytes obtained from umbilical cord blood and from adults.
The present study has shown, in corroboration, that adult and umbilical cord erythrocyte ghosts are identical in their sialic acid to protein ratio. The amount of sialic acid present at the "surface of shear" may be smaller than the total ghost sialic acid content and larger than the amount susceptible to liberation by Pronase. These values, however, form close limits around the actual surface value, since other proteolytic enzymes, trypsin and ficin, have been shown to remove, respectively, $84 \%$ and $87 \%$ of total membrane sialic acid when acting on intact erythrocytes. Both the present study and that reported by Uhlenbruck and Heggen have yielded findings in close agreement, demonstrating identical sialic acid content in surface glycoproteins of adult and umbilical cord erythrocytes.

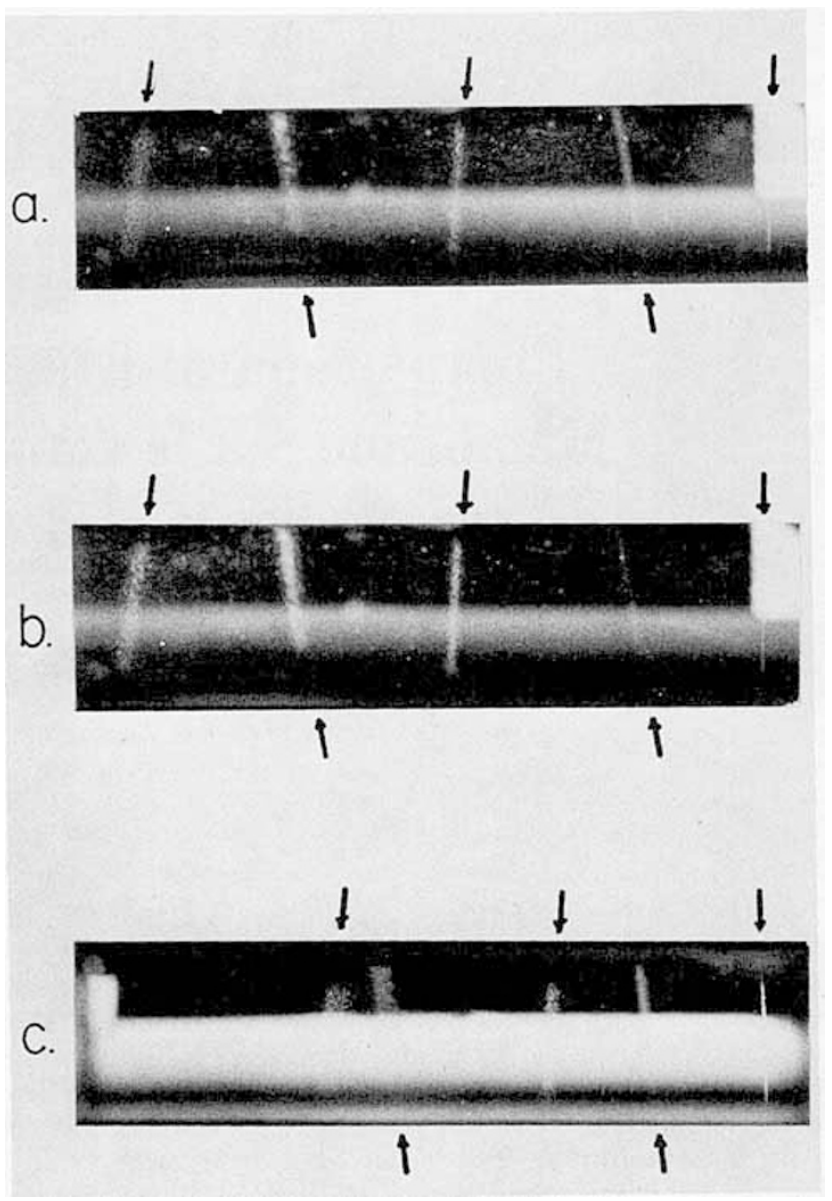

Fig. 1. Dark-field photographs of streaks generated in the endless belt electrophoresis apparatus. Each streak traverses the viewing window five times, initially entering the field of view at the right and spending an additional $20 \mathrm{sec}$ in the electric field before each successive appearance from right to left. Thus, the greatest separation attained in the apparatus appears at the far left. Streak width or separation between pairs of streaks is measured, while absolute position of streaks in the window is unimportant. Illustrated are: $a$. : erythrocytes from an adult donor; $b .:$ the same cells mixed with umbilical cord erythrocytes; $c .:$ normal adult cells mixed with $\mathrm{M}^{8}$ cells which exhibit an electrophoretic mobility $4 \%$ below normal.

Table 1. Summary of data

\begin{tabular}{lcccc}
\hline & No. of samples & $\begin{array}{c}\text { Electrophoretic mobility, } \\
10^{-4} \mathrm{~cm}^{2} \mathrm{~V}^{-1} \mathrm{sec}^{-1}\end{array}$ & No. of samples & $\begin{array}{c}\text { Sialic acid, } \\
\mathrm{nmol} / \mathrm{mg} \text { protein }\end{array}$ \\
\hline Adult & 140 & $-2.3 \pm 0.1^{1}$ & 59 & $100.4 \pm 5.9(\mathrm{SD})$ \\
Neonate & 77 & $-2.3 \pm 0.1$ & 67 & $100.1 \pm 5.4$ \\
\hline
\end{tabular}

\footnotetext{
${ }^{1}$ Limits of streak.
} 
Eylar et al. (4), using the microscopic method of electrophoresis, demonstrated an approximately proportional relationship between sialic acid content, the present finding of identical electrophoretic mobilities for adult and umbilical cord erythrocytes is consistent with the determinations of identical sialic acid content. measured at low ionic strength by endless belt electrophoresis (10). In view of these demonstrations of the correlation between electrophoretic mobility and sialic acid content, the present finding of identical electrophoretic mobilities for adult and umbilical cord erythrocytes is consistent with the determinations of identical sialic acid content.

Rottino and Angers found no statistically significant difference in electrophoretic mobility between adult and umbilical cord erythrocytes as determined by the microscopic method in Veronalacetate buffer at $\mathrm{pH} 7$ and a $7 \%$ increase for umbilical cord cells at pH 9 (13). On the other hand, Hollan et al. (17) report umbilical cord erythrocytes as showing a $12 \%$ increase over adult cells in phosphate buffer of $\mathrm{pH} 7.45$. Although a possible reason for this discrepancy might be a difference between the types of cells in the interaction of one of the membrane components with one of the buffer ions, it is also possible that erroneous results may have been introduced by difficulties in the experimental technique. Rottino and Angers found meticulous attention to technique to be essential and enumerated several sources of disturbances.

Although the results of the present study agree with those of Angers and Rottino at approximately neutral $\mathrm{pH}$, the increased mobility of umbilical cord cells which they reported at higher and lower $\mathrm{pH}$ values could not be demonstrated by endless belt electrophoresis. Both at $\mathrm{pH} 9$ and at $\mathrm{pH} 5$ mixed suspensions of the two types of cells formed single streaks with widths corresponding to an increased spread in mobility of no greater than $4 \%$. Electrophoretic mobility measurements on a mixed suspension of two cell types in a microelectrophoresis cell have been used by Einsenberg et al. (3) to demonstrate very convincingly a distinctly higher mobility for regenerating liver cells compared with normal liver cells. Electrophoretic measurements using mixed suspensions leave no doubt that measurements of both cell types were made under exactly the same conditions. This procedure was not used in the study of Rottino and Angers (13). Moreover, a second series of measurements on adult cells was reported in their paper which showed no significant differences from cord blood cells, but which was not discussed by these authors in summarizing their findings.

As work by Vassar et al. (18) disproved the generalization that malignant cells all have greater negative electrophoretic mobilities than normal cells from the same tissue, the present study should discourage the belief that any cell obtained at or before birth is an immature cell and more negatively charged (7). Although embryonic fibroblasts (6), like regenerating liver cells (3), have been shown to exhibit higher mobilities correlated with higher growth rate, the erythrocyte of umbilical cord blood is essentially uninvolved in proliferation, but like the adult cell is the terminal product of erythropoiesis.

\section{REFERENCES AND NOTES}

1. Cook, G. M. W., Heard, D. H., and Seaman, G. V. F.: Sialic acids and the electrokinetic charge of the human erythrocyte. Nature, 191: 45 (1961).

2. Dodge, J. T., Mitchell, C., and Hanahan, D. J.: The preparation and chemical characteristics of hemoglobin-free ghosts of human erythrocytes. Arch. Biochem. Biophys., 100: 119 (1963).

3. Eisenberg, S., Ben-Or, S., and Doljanski, F.: Electrokinētic properties of cells in growth processes. I. The elcetrophoretic behavior of liver cells during regeneration and post-natal growth. Exp. Cell Res., 26: 451 (1962).

4. Eylar, E. H., Madoff, M. A., Brody, O. V., and Oncley, J. L.: The contribution of sialc acid to the surface charge of the erythrocyte. J. Biol. Chem., 237: 1992 (1962).

5. Furuhjelm, U., Myllyla, G., Nevanlinna, H. R., Nordling, S., Pirkola, A., Gavin, J., Gooch, A., Sanger, R., and Tippet, P.: The red cell phenotype En(a-) and anti En ${ }^{\alpha}$ : Serological and physicochemical aspects. Vox Sang., 17: $256(1969)$.

6. Heard, D. H., Seaman, G. V. F., and Simon-Reuss, I.: Electrophoretic mobility of cultured mesodermal tissue cells. Nature, 190: 1009, (1961).

7. Hollan, S. R., Szelenyi, J. G., Breuer, J. H., Medgyesi, G. A., and Soter, V. N.: Structural and functional differences between human foetal and adult erythrocytes. Haematologia, 4: 409 (1967).

8. Lowry, O. H., Rosebrough, N. H., Farr, A. L., and Randall, R. J.: Protein measurement with the Folin phenol reagent. J. Biol. Chem., 193: 265 (1951)

9. Luner, S. J., Sturgeon, P., McQuiston, D. T., and Szklarek, D.: Physicochemical and quantitative hemagglutination studies on some MN variants. Vox Sang. (in press).

10. Luner, S. J., Sturgeon, P., Szklarek, D., and McQuiston, D. T.: Effects of proteases and neuraminidase on RBC surface charge and agglutination. Vox Sang., 28: 184 (1975).

11. Myllyla, G., Furuhjelm, U., Nordling, S., Pirkola, A., Tippet, P., Gavin, J., and Sanger, R.: Persistent mixed field polyagglutinability. Vox Sang., 17: 256 (1969).

12. Nordling, S., Sanger, R., Gavin, J., Furuhjelm, U., Myllyla, G., and Metaxas, M. N.: $\mathrm{M}^{\mathrm{g}}$ and $\mathrm{M}^{\mathrm{k}}$ : Some serological and physicochemical observations. Vox Sang., 17: 300 (1969).

13. Rottino, A., and Angers, J.: Electrophoretic mobility of the red blood cell during human pregnancy. Amer. J. Obstet. Gynecol., 82: 1302 (1961).

14. Seaman, G. V.F., and Uhlenbruck, G.: The action of proteolytic enzymes on the red cells of some animal species. Biochim. Biophys. Acta, 64: 570 (1962).

15. Sturgeon, P., Kolin, A., Kwak, K. S., and Luner, S. J.: Studies of human erythrocytes by endless belt electrophoresis. 1. A comparison of electrophoretic mobility and serological reactivity of normal and enzyme treated cells. Haematologia, 6: 93 (1972).

16. Sturgeon, P., Luner, S. J., and McQuiston, D. T.: Permanent mixed-field polyagglutinability (PMFP). II. Hematological, biophysical and biochemical observations. Vox Sang., 25: 498 (1973).

17. Uhlenbruck, G., and Heggen, M.: Uber den Glykoprotein-gehalt von Neugeborenenerythrocyten sowie einen Widerspruch im Anti- $A_{H P}$ "Blutgruppensystem." Z. Kinderheilk, 106: 260 (1969).

18. Vassar, P. S., Seaman, G. V. F., and Brooks, D. E.: Cell membrane properties in neoplasia, p. 265. In: Proceedings of the Seventh Canadian Cancer Research Conference, 1967.

19. Warren, L.: The thiobarbituric acid assay of sialic acids. J. Biol. Chem., 234: 1971 (1959).

20. The authors are grateful to $\mathrm{Mr}$. Han Kang for performing some of the sialic acid and protein assays of erythrocyte ghosts.

21. This Investigation was supported by United States Public Health Service Research Grant CA 13955 from the National Cancer Institute, National Institutes of Heaith, Bethesda, Maryland.

22. Requests for reprints should be addressed to: S. J. Luner, Ph.D., The Gwynn Hazen Cherry Memorial Lab, Department of Pediatrics, Hematology-Oncology Division, UCLA School of Medicine, Los Angeles, Calif. 90024 (USA). 23. Accepted for publication March 25, 1975 